\title{
The Contribution of Oxytocin and Vasopressin to Mammalian Social Behavior: Potential Role in Autism Spectrum Disorder
}

\author{
Hala Harony Shlomo Wagner \\ Department of Neurobiology and Ethology, Center for Gene Manipulation in the Brain, University of Haifa, \\ Haifa, Israel
}

\section{Key Words}

Oxytocin · Vasopressin • Receptors · Autism · Social

behavior $\cdot$ Amygdala cognition and behavior, and (d) discuss the possibility of the involvement of OT and AVP in ASD etiology, as well as the prospect of using these peptides as a treatment for ASD patients.

Copyright $\odot 2010$ S. Karger AG, Basel

\begin{abstract}
Oxytocin (OT) and arginine-vasopressin (AVP) are 2 peptides that are produced in the brain and released via the pituitary gland to the peripheral blood, where they have diverse physiological functions. In the last 2 decades it has become clear that these peptides also play a central role in the modulation of mammalian social behavior by their actions within the brain. Several lines of evidence suggest their involvement in autism spectrum disorder (ASD), which is known to be associated with impaired social cognition and behavior. Recent clinical trials using OT administration to autistic patients have reported promising results. Here, we aim to describe the main data that suggest a connection between these peptides and ASD. Following a short illustration of several major topics in ASD biology we will (a) briefly describe the oxytocinergic and vasopressinergic systems in the brain, (b) discuss a few compelling cases manifesting the involvement of OT and AVP in mammalian social behavior, (c) describe data supporting the role of these peptides in human social
\end{abstract}

\section{Autism Spectrum Disorder}

Symptoms

Autism is a broadly-defined developmental disorder that mainly affects behavior and cognition. It is diagnosed by symptoms in 3 categories: impairments in social behavior, verbal and nonverbal communication deficits, and repetitive movements and stereotyped behavior [1]. Social interaction impairments are the most characteristic deficits in autism spectrum disorder (ASD). These impairments include a failure to use standard nonverbal behaviors (eye contact, affective expression) to regulate social interactions with others, failure to share enjoyment, interests and achievements with others, and a lack of social and emotional reciprocity. Individuals with ASD have difficulties in showing empathy, recognizing faces and processing the affective states of others. Because the

\section{KARGER}

Fax +41613061234 E-Mail karger@karger.ch www.karger.com
(C) 2010 S. Karger AG, Base

$1424-862 X / 10 / 0182-0082 \$ 26.00 / 0$

Accessible online at:

www.karger.com/nsg
Shlomo Wagner, $\mathrm{PhD}$

Department of Biology and Department of Neurobiology and Ethology

RM 75, Biological Laboratories, University of Haifa, Mt. Carmel

IL-31905 Haifa (Israel)

Tel. +972 4828 8773, Fax +972 4828 8763, E-Mail shlomow@ research.haifa.ac.il 
severity and the age of onset of symptoms can vary greatly among different individuals, autism is highly heterogenic, hence the term 'autism spectrum disorder'.

In recent decades, there has been a sharp increase in the number of children diagnosed with autism. This increase is at least partially due to changes in the diagnosis processes and greater public awareness, but it may also reflect an actual increase in ASD cases $[2,3]$. Unlike many other brain disorders, ASD, which is $3-5$ times more common in males than in females [4], lacks any clear unifying pathology at the molecular, cellular or system levels [5]. This fact makes the exploration of the biological basis of ASD extremely challenging [6].

\section{Etiology}

Despite the intense research focus on ASD in recent years, the underlying etiology remains obscure. Genetic research involving twins and family studies strongly supports a significant contribution of genetic factors to ASD etiology $[7,8]$. Nevertheless, no particular model of genetic transmission has been implicated in ASD and no single gene has been found to cause the disorder [9]. Moreover, in recent years it has been shown that dozens of distinct genetic disorders, ranging from single nucleotide mutations to chromosomal abnormalities, can result in ASD symptoms [10]. However, these genetic disorders are only responsible for about $10 \%$ of ASD cases [11]. Thus, the genetic basis underlying ASD appears to be very complex, and could be attributed either to the combinational effects of common genetic variants or to rare mutations [12], such as chromosomal deletions and duplications that lead to the autistic phenotype [8].

In addition to the possible contributions of genetic factors, environmental elements may also play a role in causing ASD [13]. Such environmental factors may include certain foods, infectious diseases, environmental toxins, prenatal stress and others [12]. However, no single environmental factor has been shown to be a definite cause for ASD [14].

Recently, several investigators have suggested that the pathogenesis of ASD may involve epigenetic regulatory mechanisms $[15,16]$. The term 'epigenetic' is defined as heritable alterations in gene expression caused by mechanisms other than changes in DNA sequence [17]. The 2 main molecular epigenetic mechanisms are posttranslational histone modifications and DNA methylation [18]. Methylation of DNA is a direct chemical modification of a cytosine that is immediately followed by a guanine [19]. These $C p G$ dinucleotide sequences are highly underrepresented in the genome, and often occur in small clusters known as $\mathrm{CpG}$ islands [20]. Hypermethylation of $\mathrm{CpG}$ islands in the vicinity of genes is usually considered to be a transcription-suppressing mechanism [19], although it has been shown in some cases to be associated with transcription activation [21].

In 2 different monogenetic disorders associated with ASD, Rett syndrome [22] and fragile X syndrome [23], an epigenetic component was shown to be involved in the etiology of the disorder. Rett syndrome is a complex neurological disorder caused by a mutation in the methylCpG-binding protein $2[24,25]$, one of the key regulators of epigenetic processes in the brain [26]. Fragile X syndrome occurs through an expansion of a $C G G$ repeat in the $5^{\prime}$-untranslated region of the FMR1 gene, rendering the region susceptible to epigenetic silencing [27, 28]. Additional evidence for the involvement of epigenetic modifications in ASD arises from studies demonstrating a link between genomic imprinting, which is an epigenetic process responsible for the parental monoallelic expression of some genes, and susceptibility to autism $[29,30]$. Thus, it seems likely that a complex interaction between multiple genetic, environmental and epigenetic factors determines the etiology of ASD [31].

\section{Oxytocin and Vasopressin}

\section{Structure, Function and Location}

Oxytocin (OT) and arginine-vasopressin (AVP) are 'twin' 9-amino acid peptides (nonapeptides) that in mammals are produced mainly in the brain [excellently reviewed in 32,33]. They have variable hormonal actions in the periphery and the CNS. Peripheral functions of OT include regulation of uterus contractions during labor and modulation of milk ejection during suckling. Thus, OT is strongly connected to maternal functions. AVP, in contrast, is responsible for very different physiological functions, including the regulation of water absorption in the kidney. As depicted in figure 1a, these peptides are quite similar, differing from each other in only 2 positions of their 9-amino acids sequence. They are both produced by nonoverlapping populations of neurons in the same hypothalamic nuclei, the supraoptic nucleus and the paraventricular nucleus (PVN). The supraoptic nucleus and PVN contain large magnocellular peptidergic neurons that send their axons to the posterior pituitary (neurohypophysis) where they release AVP and OT into the blood (fig. 2) [34].

The PVN also harbors smaller parvocellular neurons, each expressing OT or AVP, which project to certain ar- 


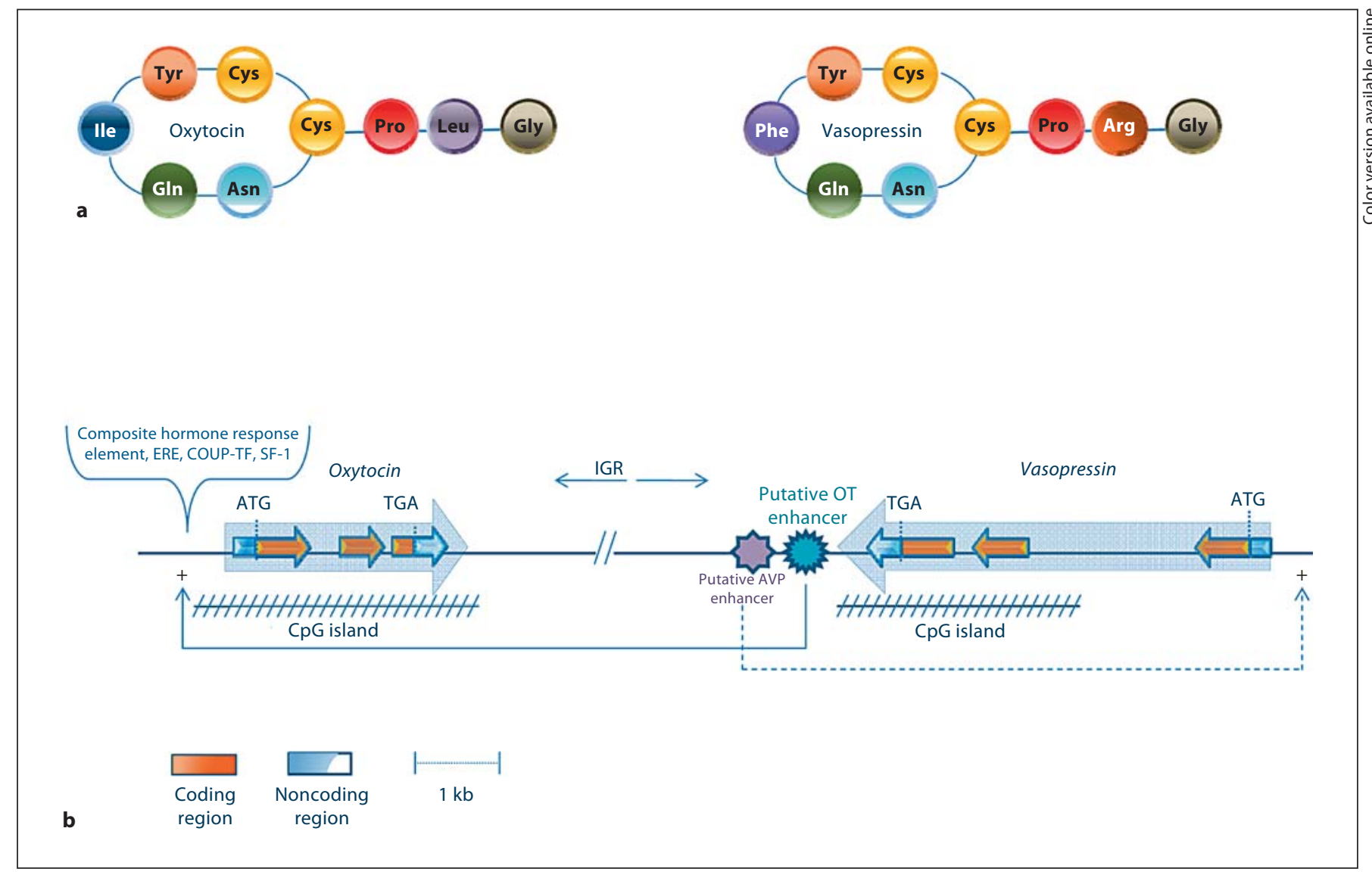

Fig. 1. The OT and AVP peptides and their genes: a Schematic structure and sequence of the OT (left) and AVP (right) peptides. Only 2 amino acids differ between these nonapeptides, both of which contain a disulfide bond between Cys residues in positions 1,6. b The genes coding for OT and AVP, which are thought to be a product of a gene duplication event, are located near each other on the genome with opposite transcription orientations. The rela- tively short intergenic region (3.6 kb in mouse) harbors enhancer elements that are important for the proper expression of both genes. The location of a CpG island, which may be involved in epigenetic regulation of gene expression, is depicted for each of the genes. A composite hormone response element which may mediate the effects of estrogen was found upstream to the OT gene. eas of the CNS. AVP is also produced in a few other brain areas, including the suprachiasmatic nucleus, the brain's circadian pacemaker, as well as the medial amygdala (MeA) and the bed nucleus of the stria terminalis (BNST) [35], which both send AVP-containing projections to the lateral septum (LS). The expression of AVP in the MeA and BNST, and hence its release in the LS, is known to be androgen-dependent, with significantly higher levels in males [36].

\section{Genes}

OT and AVP are coded by homologous genes that are thought to have emerged from a gene duplication incident prior to vertebrate divergence [37]. Accordingly, almost all invertebrates have only $1 O T / A V P$ homolog while vertebrates have $2[38,39]$. As illustrated in figure $1 \mathrm{~b}$, the mammalian OT and AVP genes are located near each other in the genome. For example, in the mouse genome they are both located on chromosome 2 [40], separated only by an intergenic region of $3.6 \mathrm{~kb}$ that contains several regulatory elements important to the proper expression of both genes [41, 42]. The mRNAs of both peptides are translated into a precursor preprohormone that, besides the nonapeptide itself and a signal peptide, contains a common polypeptide named neurophysin. This precursor is processed and cleaved in dense-core vesicles during its transport to the release sites. 
Fig. 2. The hypothalamo-neurohypophysial system: a schematic illustrating the 2 hypothalamic nuclei, the PVN and the supraoptic nucleus (SON), both of which synthesize and release OT and AVP. Also depicted is a 3rd nucleus, the suprachiasmatic nucleus (SCN), wherein AVP alone is synthesized. The magnocellular neurons of the PVN and SON, which are the main source of OT and AVP, release these 2 peptides into the blood via their projections to the posterior pituitary (neurohypophysis). The magnocellular neurons of the SON are pictured in the inset, stained for OT (red) and AVP (green) using immunocytochemical labeling.

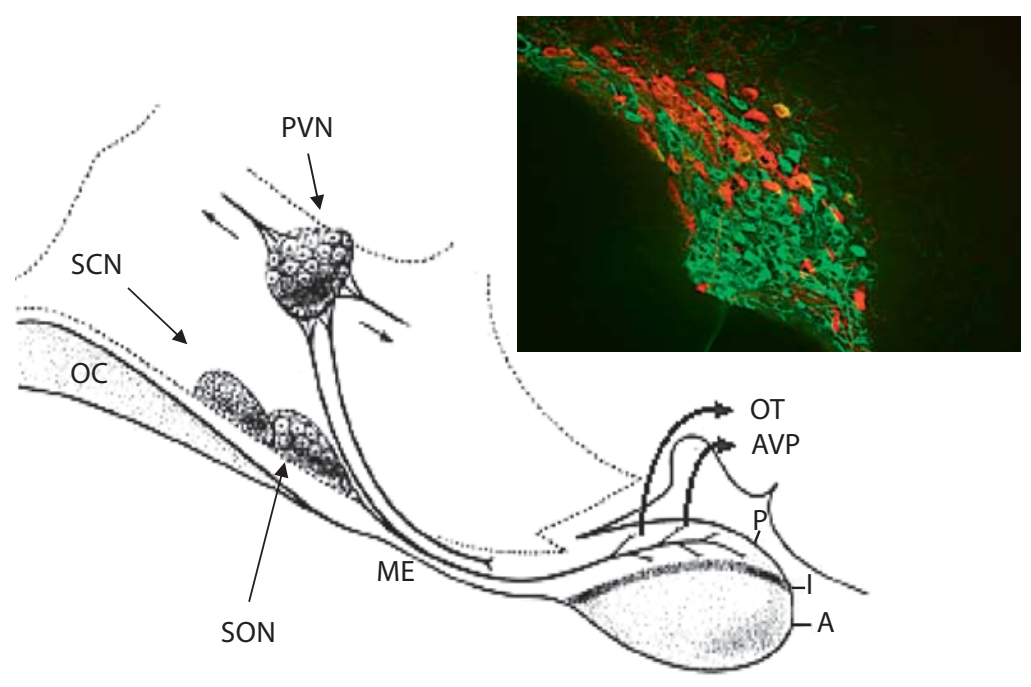

the CNS, suggesting a much wider presence of the peptides themselves. Thus, OT and AVP are likely to also have a neurohormonal action mediated by the release of the peptides from dendrites of the PVN magnocellular neurons, which are located in close proximity to the 3rd ventricle, into the ventricle, which works to change the global concentrations of OT and AVP in the CNS in response to various stimuli $[43,48]$.

\section{Receptors}

The AVP and OT signals are transuded into physiological effects via their respective AVP and OT receptors. The 3 major types of the AVP receptor (AVPR) have been typified: AVPR1a, AVPR1b and AVPR2 [32, 49]. For OT, only a single receptor type (OTR) has been identified [50]. Since the AVPR2 receptor is hardly expressed in the brain and was not shown to influence social behavior, it will not be referred to in this review.

All OT and AVP receptors are members of the G protein-coupled receptor family. Both AVPR1a and AVPR1b couple to the same type of G protein. Their ligand-binding leads to the activation of protein kinase $\mathrm{C}$ through the effector enzyme phospholipase C (PLC). In contrast to the pathway-specific coupling of the AVP receptors, the OTR binds various $G$ proteins and can therefore activate diverse 2nd messenger machineries in the same cell type [51]. 


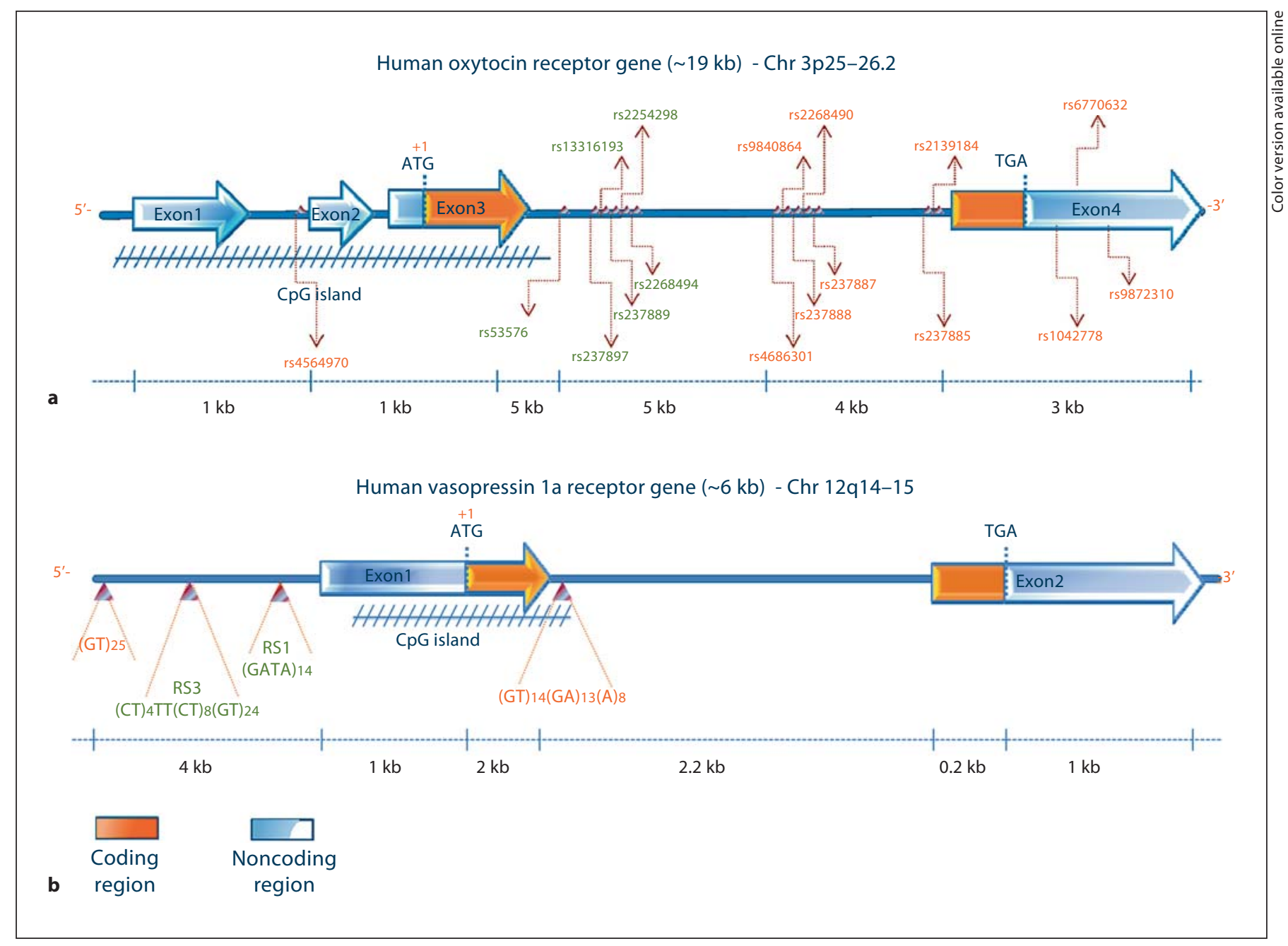

Fig. 3. The human OTR and AVPR1a genes: the locations of exons and introns, as well as CpG islands, are illustrated. Also depicted are locations of the polymorphisms (orange), some of which (green) are suspected to be genetically associated with ASD. These elements include intronic SNPs of the OTR gene (a) and microsatellite elements of the AVPR1a gene (b).

In humans, the OTR (fig. 3a) is transcribed from a single copy gene on chromosome 3p25-3p26.2 and consists of 3 introns and 4 exons [52]. The AVPR1a and $A V P R 1 b$ genes, which are each comprised of 2 exons separated by 1 large intron, are situated on distinct chromosomes in the human genome. The AVPR1a gene (fig. 3b) is located on chromosome 12q14-15 [53], while the $A V P R 1 b$ gene has been mapped on chromosome 1q32 [54]. All 3 receptors are expressed in different organs in the periphery. The OTR is expressed in the uterus, mammary gland, placenta, amnion, ovary, testis, thymus, heart and kidney [55]. The AVPR1a is mainly found in the kidney, liver and in the vascular system [53]. The AVPR1b is prominent in the anterior pituitary, but was also detected in various peripheral organs including the kidney, thymus, heart, lung, spleen, uterus and breast [56]. In addition to their peripheral distribution, OTR and AVPR1a are widely expressed in the brain while AVPR1b brain expression is much more restricted [57].

\section{Distribution of OT and AVP Receptors in the Brain}

The OTR and AVPRla expression profiles in rat and hamster brains have been investigated by several research groups. Results [reviewed in 33,55 ] have indicated that the expression profile of both receptors is not only brainregion specific, but also sex-specific and influenced by 
gonadal steroids. Moreover, studies that focused on these receptors' expression patterns in the brain revealed that they exhibit highly species-specific distribution profiles. For example, in the rat brain, OTR is highly expressed in the hippocampal ventral subiculum [58]. However, no such expression has been detected in the hamster, guinea pig, rabbit or human brains. These facts suggest a complex regulation of the expression of these receptors. In the human brain, OTR was found to be expressed in several subcortical areas including the basal nucleus of Meynert, areas of the basal nuclei such as the globus pallidus, limbic areas such as the lateral septum, hypothalamic areas such as the mammillary nuclei, and in brainstem areas such as the substantia nigra pars compacta [55].

Overall, the sharp contrast between the evolutionarily conserved, spatially restricted expression of the peptides themselves and the widespread, species- and sex-specific expression of their receptors lends credence to the notion that it is the receptor distribution which governs the OT and AVP influence on the highly variable mammalian social behavior $[59,60]$.

\section{Expression Regulation of OT and AVP Receptors}

As previously mentioned, sex steroids seem to be part of the mechanisms regulating the brain's oxytocinergic and vasopressinergic systems [61]. Estrogen is the most well-studied gonadal steroid in respect to its effect on the receptors' expression. For example, OTR levels in the uterine and mammary myoepithelium increase markedly in response to estrogen at late pregnancy [62]. In the rat $O T R$ promoter region, there is a classical estrogen response element that likely mediates the sex-specific effects of estrogen on the gene transcription [63]. Moreover, the OTR promoter includes other regulatory elements such as IL-1 $\beta$, IL-6, AP-1 and APRE, all of which could be vital for the transcriptional regulation of the OTR gene $[55,64,65]$.

Repeated elements or microsatellites within gene promoters could also regulate transcription. Such elements exist in the AVPR1a promoter region, and were found to determine the species-specific expression pattern of the AVPR1a in the vole brain [66], as will be discussed in detail below.

In addition to genetic regulatory elements, transcription is also regulated by epigenetic mechanisms that may mediate tissue and sex-specific gene expression [18]. So far, 3 different studies have supported the hypothesis that OTR expression is regulated by DNA methylation. The 1st study confirmed that hypermethylation of a regulatory element within the $3 \mathrm{rd}$ intron of the human OTR gene is associated with its low levels of expression in nonexpressing tissues [67]. The 2 nd study demonstrated that growing the human hepatocellular carcinoma cells with the demethylating agent, 5-azacytidine, dramatically increases OTR mRNA levels. This research pointed to a CpG island located between 140 bp upstream and 2,338 bp downstream of the human OTR transcription start site where a 400-bp region was found to be highly methylated in the liver, a tissue in which the OTR gene is constitutively silenced [68]. A 3rd study found that hypermethylation of several $C P G$ sites within the human OTR promoter was associated with decreased levels of the OTR mRNA in the temporal cortex tissue of individuals with ASD as compared to age-matched controls [69]. This study strengthens the association between DNA methylation of the OTR promoter and the expression of the gene, and suggests a role for OTR gene methylation in ASD.

\section{OT, AVP and Animal Social Behavior}

As mentioned above, OT and AVP are highly conserved in the animal world, with homologs existing at least 700 million years ago $[38,39]$. Studies in widely diverse animal species, ranging from worms to humans, have shown that the role of OT/AVP homologs in modulation of social and reproductive behavior was also conserved during evolution [70]. Overall, AVP seems to play a larger role in male behavior, especially those behaviors related to reproductive functions, while OT is more frequently associated with female activities [61]. Both peptides, however, have behavioral roles in males and females. Below we will discuss a few of the most compelling studies which demonstrate the central role of OT and AVP in the social behavior of several distinct mammalian species.

\section{Maternal Behavior in Rats and Sheep}

During birth, the female body undergoes a series of extreme physiological changes within a short period of time. In most mammals, these physiological changes are accompanied by a rapid onset of maternal behaviors, which are primed by the high level of plasma estrogen during late pregnancy. In rats, maternal behavior is initiated only after parturition as virgin females avoid pups. Rat maternal behavior includes nest building, lactation and maternal aggression towards intruders, as well as pup licking, grooming and retrieval [71].

Several brain areas have been implicated in postpartum maternal behavior, including the hypothalamic 
MPOA, the BNST and the LS. OTR mRNA levels in these areas are higher around the time of birth, probably due to the high estrogen level [72-74], and were found to be correlated with the level of maternal behavior displayed by female rats [75]. Peripheral and central levels of OT are highest postpartum due to induction of OT release from the brain by a combination of vaginocervical stimulation during birth and the lactation activity immediately following it [55]. Thus, OT was suspected of having a role in the postpartum induction of mammalian maternal behavior [76]. Indeed, following priming with estrogen, virgin female rats centrally infused with OT display full maternal behavior [77]. Accordingly, infusion with an OTR antagonist could block the postpartum onset of maternal behavior in rats $[78,79]$. Using fMRI imaging Febo et al. [80] showed that OT administration to postpartum female rats initiated activity in brain areas which are active during pup suckling. In sheep too, central OT administration, as well as endogenous OT release induced by vaginocervical stimulation, stimulate maternal behavior in estrogen-primed nonpregnant females [81]. Moreover, a ewe is able to recognize and selectively feed its own lamb from the moment it is born. This olfactory memory of the lamb was shown to be facilitated by central OT release in the olfactory bulb [82]. These studies implicate OT in the induction of maternal behavior in mammals.

\section{Pair Bonding in Voles}

Voles (genus Microtus) show a diverse social structure amongst their different species. Prairie voles, for example, are monogamous, a behavior rarely seen among mammals. Male and female prairie voles form long-term bonds that typically last until one partner dies. In the lab, sexually inexperienced voles exhibit nonselective affiliation behavior. However, following mating, both the male and female show behavioral changes indicative of pair bonding, such as sharing a nest and displaying extensive parental behavior [83].

Most importantly, prairie voles show a strong preference for a familiar mate versus a stranger, a preference that is used for a quantitative test assessing pair bonding. During the test the examined animal is placed in a central chamber, which is connected by tubes on both sides to lateral chambers. Two stimulus animals, usually a mate and a stranger, are placed in the lateral chambers. The time spent by the examined animal in each of the chambers serves as an indication of the animal's preference. Several studies demonstrated that following mating, prairie voles spent much more time with their mate than with a stranger [84].
In contrast, members of nonmonogamous vole species, such as meadow and montane voles, do not show any preference towards a mate. The fact that these evolutionarily close species show such divergent social behavior provides an excellent opportunity for comparative investigations into the biological mechanisms underlying pair bonding [83-85].

Early studies have shown that CNS infusion with OT or AVP enhances mate preference, while infusion of OTR and AVPRla antagonists impairs mate preference [86]. These effects seem to be sex-dependent: AVP is more effective in males, and OT is more effective in females. In addition, neuroanatomical studies have found that while monogamous and nonmonogamous species have very similar distribution patterns of OT and AVP cells and projections, major differences exist in the distribution patterns of their receptors in the brain, mainly in limbic areas. For example, the monogamous prairie voles express significantly more OTR in the nucleus accumbens and AVPR1a in the ventral pallidum, while the nonmonogamous montane and meadow voles express higher levels of both receptors in the LS and ventromedial hypothalamus. These studies [reviewed in 87,88 ] suggest that pair bonding, which differs markedly between vole species, is regulated by central OT and AVP.

Indeed, functional studies have shown that OT and AVP actions in specific brain areas are responsible for certain aspects of the voles' social behavior. For example, local infusion of OTR antagonist into the nucleus accumbens of female prairie voles or AVPR1a antagonist into the ventral pallidum of male prairie voles inhibited their mate preference. Most astonishing, overexpression of the AVPR1a in the ventral pallidum of meadow vole males induced partner preference behavior in these nonmonogamous animals [89]. These results [reviewed in 59, 60, 83, 87, 88, 90, 91] suggest that a change in the expression of a single gene (the AVPR1a) in a specific area of the adult brain may create a robust change in the animal's social behavior.

One genetic factor that may be responsible for the difference in the AVPR1a brain expression pattern between prairie and meadow voles is a microsatellite DNA element located $660 \mathrm{bp}$ upstream to the transcription start site of the AVPR $1 a$ gene. This repetitive DNA is on average 500 bp long in prairie voles, but only 50 bp long in the nonmonogamous meadow and montane voles [66, 92]. Moreover, even within prairie voles, interspecies differences in the microsatellite length seem to have an impact on the animal's social behavior: it was found that animals with a longer microsatellite are more prosocial than those with a shorter microsatellite $[83,93]$. These results suggest that 
Fig. 4. Social recognition memory in mice depends on OT activity in the MeA and AVP activity in the lateral septum. a Left: Social recognition memory paradigm with wild-type (empty dots) and OTknockout mice (black dots) show that $O T$ knockout mice are impaired with regard to social recognition memory, and therefore investigate familiar and novel conspecifics for the same duration of time. Right: Fos immunostaining shows the lack of activity in the MeA of an OT-knockout mouse (lower picture) following an encounter with a novel juvenile, as compared to a wild-type mouse (upper picture). b Left: While AVPR1a-knockout mice (black dots) are impaired in their social recognition memory, overexpression of the gene in the lateral septum using a viral vector (empty dots) is sufficient to restore social memory. Right: Autoradiography shows the lack of AVPR1a-binding sites (dark staining) in the brain of a knockout mouse (upper picture) compared to the strong expression of binding sites following viralmediated gene delivery to the lateral septum (lower panel). Adapted from Lim and Young [60].
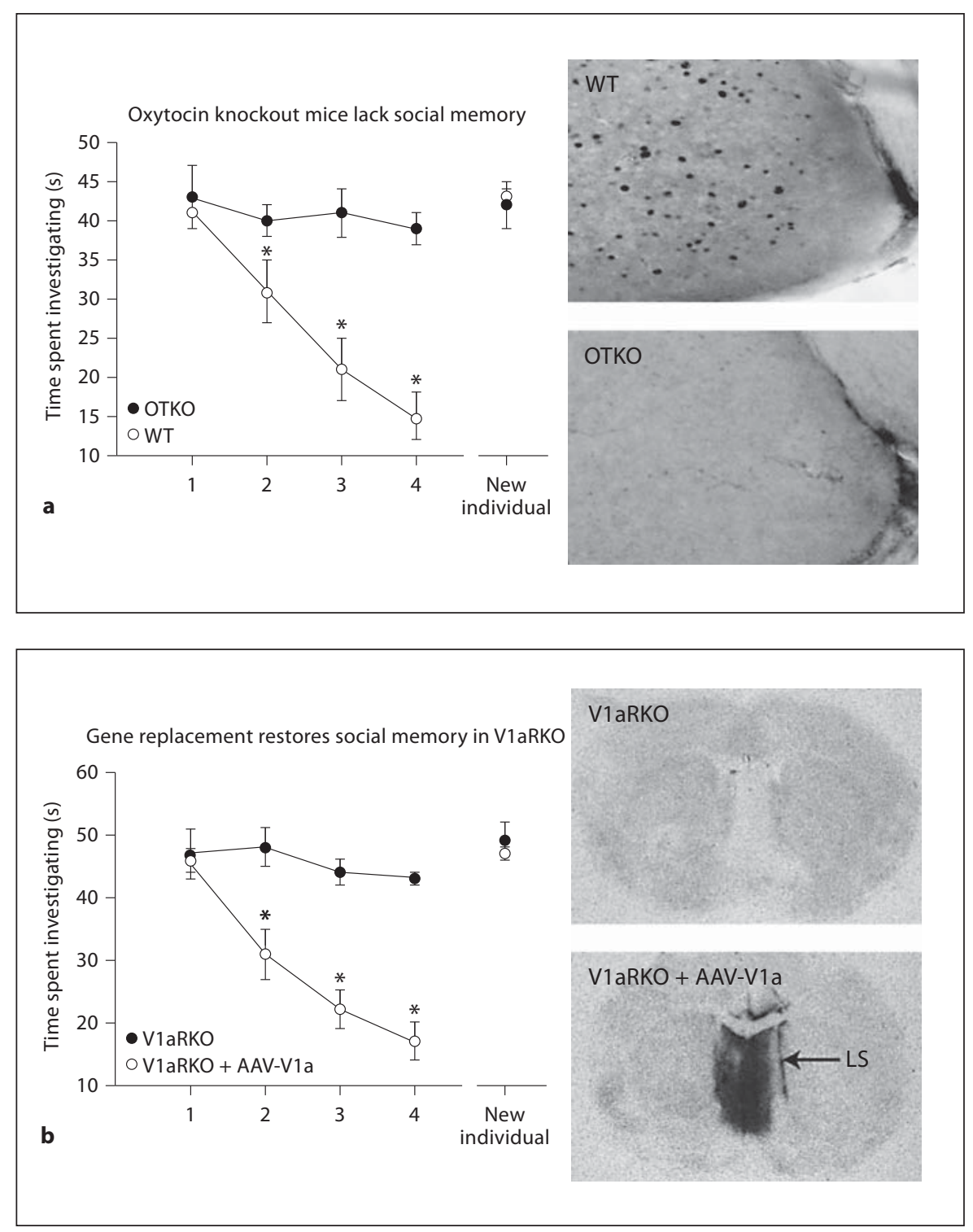

diverse alleles of genetic untranscribed elements may influence the variability in social behavior within a population of animals.

\section{Social Recognition Memory in Rats and Mice}

The ability of an animal to recognize a familiar individual is critical for many aspects of mammalian social behavior, especially for establishing family relationships and clan organization. In some cases, recognizing only general characteristics of the individual - such as strain, gender or reproductive state - may be sufficient. In other cases, it is advantageous to recognize the specific individual by remembering its specific features.
Most mammals rely primarily on olfactory cues for social recognition. A meeting between 2 unfamiliar rats or mice usually starts with a period of intensive olfactory investigation, mainly at the face and anogenital regions, which precedes further social interactions such as mating or aggressive interaction.

Based on the natural tendency of rats and mice to closely investigate novel individuals, a simple laboratory test to investigate social recognition memory capacities was developed [94]. In this test, an unfamiliar juvenile conspecific is introduced into the cage of a resident adult rat for a period of $5 \mathrm{~min}$. The time spent by the adult rat on olfactory investigation of the juvenile is measured. 
Then, following an interval (usually $30-120 \mathrm{~min}$ ) the same juvenile is reintroduced into the cage and again, the time spent by the adult rat on olfactory investigation of the juvenile is measured. If the 2 measured times do not differ significantly, it can be deduced that the adult rat did not recognize the juvenile. If, however, the adult rat spent less time investigating the juvenile on the 2nd meeting, it can be deduced that the adult rat had a memory trace of the juvenile.

In a more elaborate version of the test, this procedure is repeated several (usually 4) times with the same juvenile, until the adult displays a very short investigation time. The last (5th) encounter is with an unfamiliar juvenile to control for fatigue or stimulus-unspecific habituation. Following this type of habituation-dishabituation paradigm, the adult rat can remember the tested juvenile for at least a week (Wagner, unpubl. results).

Both OT and AVP were found to be crucial for social recognition memory in rats and mice (reviewed in [9597]). As shown in figure 4a, OT-knockout [98] (and OTRknockout [99]) male and female mice showed a specific loss of social recognition memory even though they displayed a normal sense of smell [100]. In the case of OTknockout mice, injection of OT into the MeA prior to the first exposure to the juvenile enabled social recognition memory in the injected adult [101]. Thus, OT action in the MeA seems to be crucial for social recognition memory. Indeed, MeA-specific OTR disruption by antisense injection caused impairment in social recognition memory [102]. OT infusion to other brain areas, such as the $\mathrm{OB}$ and LS, was also found to enhance social memory [103]. Therefore, it seems that OT may act in several brain regions to modulate the effect of social stimuli [104, 105].

AVP also plays an important role in social recognition memory. For example, Brattleboro rats, which carry a spontaneous null mutation in the $A V P$ gene, are impaired in social recognition memory [106], similar to AVPR1aknockout mice [107]. In the case of AVP, it seems that the LS is the most important brain area for social recognition: infusion of AVP into the LS of Brattleboro rats [106] restores social recognition memory, as does viral-mediated delivery of a functional AVPR $1 a$ gene into the LS of AVPR1a-knockout mice [108] (fig. 4b). However, the LS may not be the only brain area involved: a recently discovered population of AVP-expressing neurons in the OB of rats may also be instrumental for social recognition memory [109].

Overall, animal studies that have investigated the role of OT and AVP in social behavior point to a concerted action of these peptides in specific brain areas that modulate a neuronal network responsible for certain aspects of mammalian social behavior $[59,70]$.

\section{Oxytocin, Vasopressin and Human Social Behavior}

When summarizing the data regarding the role of OT and AVP in human social behavior, it is important to note that most human studies correlate various parameters with peptide concentrations in either the blood, saliva or urine, fluids that can be collected with no or minimal invasion. However, it is the cerebrospinal fluid concentration that is the truly relevant measure. In addition, many studies that deal with the human response to the peptides deliver them via intravenous infusion. In these cases, only a small fraction of the peptides penetrates the bloodbrain barrier and arrive at the brain. Recently, more studies are beginning to use intranasal application of peptides to deliver them efficiently to the CNS [110]. This relatively new method may also be used in the near future for therapeutic applications.

\section{Anxiety}

In humans, AVP seems to play an anxiogenic role [33]. Elevated expression of AVP in the PVN is associated with an increased level of anxiety and arousal. In contrast, OT causes relaxation and a decrease in anxiety levels. This effect of OT is at least partially caused by the inhibition of the hypothalamic-pituitary-adrenal axis. Endogenous OT release in lactating women is associated with decreased levels of plasma ACTH and cortisol as well as reduced stress responses [111-113]. Similar results were obtained with women receiving positive physical contact [114]. Moreover, exogenous application of OT was shown to act synergistically with social support to reduce endocrine and psychological stress responses [115]. Furthermore, intranasal delivery of OT was shown to increase positive communication and reduce cortisol levels during couple conflict [116].

Another mechanism by which OT may reduce anxiety is via modulation of amygdala-mediated autonomic fear responses through amygdala OT receptors. fMRI studies have shown that exogenous OT infusion reduces fear responses in the amygdala [117-120].

Trust

In humans, trust is necessary for social approach and affiliation. In a landmark study, Fehr and his colleagues [121] used a monetary game to assess the effect of OT on 
trust in humans. In the experiment, male volunteers were given a sum of money and were presented with the opportunity to invest a portion of it in the hands of an unknown partner. Investing in the other partner could lead to higher payoffs for both players, but the investor always ran the risk of losing the invested money in the hands of the trustee. The researchers found that intranasally-delivered OT caused a significant increase, as compared to the placebo, in the individual's willingness to accept risks that arose through interpersonal interactions. Later, they showed that the same treatment prevented people from losing trust in others who had breached it [122]. Using fMRI, they found that this effect of OT was associated with a reduction of activity in several brain regions linked to fear processing, including the amygdala.

\section{Social Cognition}

Intranasal OT administration enhanced the ability of humans to recognize the affective state of other individuals from facial cues [123]. It also increased the duration of their gazes towards the eye region of faces [124]. Recently, it was found that intranasally administered OT increased the ratings of facial trustworthiness and attractiveness [125] and enhanced processing and memory of positivelyexpressing faces $[126,127]$. Additionally, several studies have shown that OT plays a role in human parenting [128-130]. Altogether, these results suggest that OT plays a role in facial processing and human interpersonal communication.

Interestingly, a study by Shamay-Tsoory et al. [131] demonstrated that OT administration facilitated envy (when the subject believed that he/she earned less money in a monetary game than the other participant) and enhanced gloating over the other's misfortune (when the subject believed that he/she earned more than the other participant). These results suggest that OT is not merely a prosocial neurohormone, but also plays a complicated role in a wide range of social behaviors [132, 133]. Moreover, De Dreu et al. [134] recently used an intergroup monetary game (intergroup prisoners' dilemma-maximizing differences game) to investigate the role of OT in parochial altruism in the context of intergroup conflict in humans. Their results clearly show that OT administration (compared with placebo) drives a 'tend and defend' response which enhances in-group trust and cooperation, and at the same time promotes defensive, but not offensive, aggression toward competing out-groups. These results support the hypothesis that the oxytocinergic system in the human brain is part of evolutionary adaptation that contributes to individual survival by pro- moting and maintaining social life, hence enhancing group protection against eminent threats, including competing out-groups.

\section{Human AVPR1a and OTR Genes}

The human OTR and AVPRla genes each contain a distinct type of polymorphism in noncoding sequences that were shown to be associated with changes in social behavior $[135,136]$. In the case of $A V P R 1 a$, the main polymorphism is in 4 microsatellite elements that are located in the promoter and intronic regions (fig. 3b). Of these elements, the most well-studied is the RS3, whose length varies between distinct alleles of the AVPR1a gene. Using the monetary 'dictator' game, Knafo et al. [137] demonstrated a positive correlation between the length of the $R S 3$ element and the level of altruistic behavior displayed by males. A genetic association was also found between the $R S 3$ polymorphism and several aspects of male marital bonding in a sample of 552 Swedish twin pairs [138]. In addition, RS3 length was associated with the age of first sexual intercourse in males and females [139]. Moreover, an fMRI study revealed a correlation between $R S 3$ length and activity in the amygdala of male subjects in response to fearful faces [140].

These studies, taken together, suggest an association between polymorphism in microsatellite elements in the human AVPR1a gene promoter and male social behavior [135]. This association is similar to the one found in voles between the microsatellite element of the AVPR1a gene and male social behavior [66]. However, as long as the mechanism by which the polymorphism in the untranscribed microsatellite element exerts its action on receptor function remains unknown, the linkage between it and social behavior remains tentative. The requested mechanism may involve influence of the microsatellite element on the regulation of the AVPRla gene transcription. Such an effect is supported by a correlation found between the receptor mRNA level in human postmortem hippocampus and the RS3 length [137].

The human OTR gene spans roughly $19 \mathrm{~kb}$ and comprises 4 exons and 3 introns, harboring more than 30 mostly intronic single nucleotide polymorphisms (SNPs; fig. 3a). In a polymorphic region of the 3rd exon, which was found to regulate the gene expression [67], a single SNP (rs53576) was shown to be genetically associated with empathy and response to stress in male and female college students [141]. In a different study, the same SNP was found to be genetically associated with parental sensitivity $[142,143]$. In both studies the $G G$ allele was more prosocial than the $A A$ and $A G$ alleles. 
A significant association was also observed between 3 single-tagging SNPs across the OTR gene region and human social behavior [144]. This behavior was modeled by the dictator game and another related paradigm, the social values orientation task. Both paradigms measure altruism and prosocial decisions.

Overall, genetic studies of the human OTR and AVPR 1a genes suggest a strong but complicated association of polymorphisms in noncoding sequences of the receptor genes with various aspects of human social activity $[135,136,145]$. Nevertheless, the genetic mechanisms by which these polymorphisms exert their effects on behavior remain unclear. In vitro studies examining the direct impact of these polymorphisms on gene expression might close this gap.

\section{OT, AVP and ASD}

Because of their central role in mammalian social behavior, it is tempting to suspect that these neuropeptides are involved in the etiology of ASD [146], a disorder that is characterized by impaired social behavior and cognition. Indeed, several indications do point in that direction: first, dysfunction of the amygdala has been hypothesized to play a role in the development of ASD [147, 148]. This brain area shows a particularly strong expression of OT and AVP receptors [32, 33]. Moreover, OT administration and polymorphisms in the AVPR1a gene were found to affect amygdala responses in humans $[119,140$, 149]. Second, individuals with ASD show a specific deficit in face recognition [1], which may be related to the specific deficits of OT-knockout and OTR-knockout mice in social recognition memory $[95,150]$. Third, OT administration to humans was found to enhance the ability of inferring the mental states of others [123], an ability which is specifically impaired in ASD patients [1].

Fourth, ASD is well known to be sexually biased, with a rate of occurrence that is 3-5 times higher in males. The influence of OT and AVP on animal behavior is also known to be sexually biased, with stronger effects of OT on females and of AVP in males [61]. Furthermore, both the oxytocynergic and vasopressinergic systems in the mammalian brain are known to be sexually-dimorphic $[151,152]$. Specifically, the expression of AVP in the MeA and BNST, 2 brain regions that were shown to play a central role in social and reproductive mammalian behavior, is much higher in males [36]. Thus, the sex-biased OT and AVP activity in the brain may be related to the sex-biased occurrence of ASD.
The connection between OT and ASD is also supported by several lines of direct evidence, which is discussed below: (1) plasma OT levels were shown to be lower in children with ASD relative to controls, (2) genetic associations between polymorphisms in the OT and AVP receptors and ASD, (3) hypermethylation of the OTR promoter in ASD patients, and (4) OT administration was found to improve social cognition and reduce stereotypic movements in people with ASD.

(1) Modahl et al. [153] reported a significantly lower level of plasma OT in children with low-functioning autism relative to age-matched controls. Later, these same researchers [154] reported that the low plasma OT levels in autistic individuals were correlated with higher levels of unprocessed OT precursor (OT-X) that may be explained by impaired processing of OT. Recently, Andari et al. [155] published similar observations of highfunctioning autistic patients. On the other hand, Jansen et al. [156] found higher plasma OT levels than controls in adult individuals with ASD. This discrepancy could be explained by the different developmental stages of the subjects tested in the distinct studies (children vs. adults).

(2) Two genome-wide studies have identified the genomic region of the OTR (3p25.3) as a promising linkage site for ASD $[157,158]$. Explorations of copy number variations associated with ASD identified several cases with deletions in chromosome 3 which abolished the OTR $[69,159]$. Four independent genetic linkage and linkage disequilibrium studies in different populations, including a family-based study, have shown a genetic association between several SNPs of the human OTR and ASD [160-163]. One of these SNPs, rs2254298, was found to be associated with ASD in all 4 studies. A 5th study showed an association not only with the OTR, but also with the OT gene and ASD [164]. On the other hand, a study using 3 independent Caucasian populations found no genetic association between ASD with 18 SNPs of the OTR [165]. Nevertheless, this study did show a correlation between intronic SNPs in the OTR gene and mRNA levels in peripheral lymphocytes and postmortem amygdala tissue, hinting to a possible effect of these SNPs on the receptor expression. The AVPR1a gene was also shown to be genetically linked with ASD by 3 independent linkage and linkage disequilibrium studies [166-168] which found a genetic association between ASD and polymorphism in the microsatellite elements of the AVPR1a promoter. Overall, these studies support a weak genetic linkage between ASD and the OTR and AVPR1a genes. 
(3) Recently, Gregory et al. [69] used genome-wide microarrays to identify copy-number variants in 119 individuals with ASD from multiplex autism families. They found a family in which one affected member had a heterozygotic deletion in the OTR gene, which he inherited from his mother. An affected sibling did not possess the deletion allele, but had a hypermethylated promoter of the OTR gene. The researchers hypothesized that such hypermethylation of the OTR promoter may cause downregulation of its expression, hence a similar phenotype to the deletion of the gene. To challenge this hypothesis, they examined DNA methylation at this region in 20 autistic individuals and 20 controls. Their results showed that individuals with ASD had a significantly higher methylation in 3 $C p G$ sites in the OTR promoter as compared to controls. In addition, an examination of postmortem temporal cortex tissue from autistic individuals revealed the sites to be hypermethylated as compared to agematched controls. This hypermethylation was correlated with a $20 \%$ reduction in OTR mRNA levels in the tissue of autistic individuals as compared to controls. The results of this study implicate, for the first time, the epigenetic regulation of OTR in the development of the disorder.

(4) In 2003, Hollander et al. [169] published the results of the first study exploring the effect of OT administration on subjects with ASD. They have conducted a double-blind placebo experiment in which OT was intravenously administered to 15 adults with ASD, each completing both OT and placebo challenges, hence serving as his or her own control. The OT/placebo was continuously infused during a 4-hour period during which repetitive behavior, one of the core symptoms of ASD, was assessed at 5 time points. Results showed that the frequency of repetitive behaviors decreased during the OT periods as compared to the placebo periods.

In a 2nd study, Hollander et al. [170] found that similar treatment induced long-term ( 2 weeks) improvement in the comprehension of affective speech by individuals with ASD, whereas the placebo had only a shortterm effect. Preliminary data from the same group [171] show similar improvements using intranasal delivery of OT.

Recently, Andari et al. [155] investigated the behavioral effect of OT inhalation on 13 individuals with ASD. They found that OT enhanced interactions with the partner as well as feelings of trust and preference, and selectively increased the duration of gaze in the eye region of the face in pictures presented to the participants, an effect that is considered to be prosocial. In another recent study, Guastella et al. [172] showed improvement in the ability of subjects with ASD to recognize emotional states of others following intranasal OT administration. Altogether, these results suggest a therapeutic potential of OT through its action on the core dimensions of ASD.

\section{Conclusions and Future Directions}

It is clear that OT and AVP activities in the brain play an important role in mammalian social behavior [59]. However, their direct effects on neuronal activity, as well as their underlying mechanisms, remain unknown. Recent studies in humans have shown that social cognition and behavior are significantly modulated by these 2 peptides [173]. Do these peptides play a role in the etiology of ASD? Despite several sets of data supporting such a claim, it is still difficult to answer this question, as the biology underlying ASD is not well-understood. Nevertheless, the ability to efficiently deliver the peptides to the CNS via intranasal application and the resulting influence on human social behavior suggest that even if the brain oxytocinergic and vasopressinergic systems are not involved in ASD etiology, these peptides may be used to reduce ASD symptoms [171]. They can also be combined with other interventions, such as psychological and behavioral treatments, to improve the condition of individuals with ASD.

\section{Acknowledgments}

We thank Dr. Harold Gainer and Dr. Larry Young for generous help with the figures in this paper. This work has been supported by grant No. 1901/08 of the Bio-Med Morasha Program of the Israel Science Foundation and grant No. 3613 of the Autism Speaks Foundation.

References

Neurosignals 2010;18:82-97
1 Caronna EB, Milunsky JM, Tager-Flusberg $\mathrm{H}$ : Autism spectrum disorders: clinical and research frontiers. Arch Dis Child 2008;93: 518-523.

2 Inglese MD, Elder JH: Caring for children with autism spectrum disorder. Part I: prevalence, etiology, and core features. J Pediatr Nurs 2009;24:41-48.

- 3 Fombone E: Prevalence of childhood disintegrative disorder. Autism 2002;6:149-157.

4 Steyaert JG, De la Marche W: What's new in autism? Eur J Pediatr 2008;167:1091-1101. 
5 Geschwind DH: Advances in autism. Annu Rev Med 2009;60:367-380.

$\checkmark 6$ Pardo CA, Eberhart CG: The neurobiology of autism. Brain Pathol 2007;17:434-447.

7 Abrahams BS, Geschwind DH: Advances in autism genetics: on the threshold of a new neurobiology. Nat Rev Genet 2008;9:341355.

-8 Bill BR, Geschwind DH: Genetic advances in autism: heterogeneity and convergence on shared pathways. Curr Opin Genet Dev 2009;19:271-278.

$\checkmark 9$ Happe F, Ronald A: The 'fractionable autism triad': a review of evidence from behavioural, genetic, cognitive and neural research. Neuropsychol Rev 2008;18:287-304.

10 Kumar RA, Christian SL: Genetics of autism spectrum disorders. Curr Neurol Neurosci Rep 2009;9:188-197.

11 Geschwind DH: Autism: many genes, common pathways? Cell 2008;135:391-395.

$\checkmark 12$ Buxbaum JD: Multiple rare variants in the etiology of autism spectrum disorders. Dialogues Clin Neurosci 2009;11:35-43.

13 Herbert MR: Contributions of the environment and environmentally vulnerable physiology to autism spectrum disorders. Curr Opin Neurol;23:103-110.

-14 Newschaffer CJ, Croen LA, Daniels J, Giarelli E, Grether JK, Levy SE, Mandell DS, Miller LA, Pinto-Martin J, Reaven J, Reynolds AM, Rice CE, Schendel D, Windham GC: The epidemiology of autism spectrum disorders. Annu Rev Public Health 2007;28:235-258.

-15 Jones JR, Skinner C, Friez MJ, Schwartz CE, Stevenson RE: Hypothesis: dysregulation of methylation of brain-expressed genes on the $\mathrm{X}$ chromosome and autism spectrum disorders. Am J Med Genet A 2008;146A:22132220.

$\checkmark 16$ Schanen NC: Epigenetics of autism spectrum disorders. Hum Mol Genet 2006; 152:R138-R150.

-17 Berger SL, Kouzarides T, Shiekhattar R, Shilatifard A: An operational definition of epigenetics. Genes Dev 2009;23:781-783.

-18 Jaenisch R, Bird A: Epigenetic regulation of gene expression: how the genome integrates intrinsic and environmental signals. Nat Genet 2003;33(Suppl):245-254.

19 Miranda TB, Jones PA: DNA methylation: the nuts and bolts of repression. J Cell Physiol 2007;213:384-390.

20 Klose RJ, Bird AP: Genomic DNA methylation: the mark and its mediators. Trends Biochem Sci 2006;31:89-97.

-21 Chahrour M, Jung SY, Shaw C, Zhou X, Wong ST, Qin J, Zoghbi HY: MeCP2, a key contributor to neurological disease, activates and represses transcription. Science 2008; 320:1224-1229.

-22 Lasalle JM, Yasui DH: Evolving role of MeCP2 in Rett syndrome and autism. Epigenomics 2009; 1:119-130.

-23 Garber KB, Visootsak J, Warren ST: Fragile X syndrome. Eur J Hum Genet 2008; 16:666672 .
24 Chahrour M, Zoghbi HY: The story of Rett syndrome: from clinic to neurobiology. Neuron 2007;56:422-437.

25 LaSalle JM: The odyssey of MeCP2 and parental imprinting. Epigenetics 2007;2:5-10.

26 Gonzales ML, LaSalle JM: The role of MeCP2 in brain development and neurodevelopmental disorders. Curr Psychiatry Rep 2010; 12:127-134.

$\checkmark 27$ D'Hulst C, Kooy RF: Fragile X syndrome: from molecular genetics to therapy. J Med Genet 2009;46:577-584.

28 Belmonte MK, Bourgeron T: Fragile X syndrome and autism at the intersection of genetic and neural networks. Nat Neurosci 2006;9:1221-1225.

29 Badcock C, Crespi B: Imbalanced genomic imprinting in brain development: an evolutionary basis for the aetiology of autism. J Evol Biol 2006;19:1007-1032.

>30 Hogart A, Nagarajan RP, Patzel KA, Yasui DH, Lasalle JM: 15q11-13 GABAA receptor genes are normally biallelically expressed in brain yet are subject to epigenetic dysregulation in autism-spectrum disorders. Hum Mol Genet 2007;16:691-703.

31 Happe F, Ronald A, Plomin R: Time to give up on a single explanation for autism. Nat Neurosci 2006;9:1218-1220.

32 Caldwell HK, Lee HJ, Macbeth AH, Young WS 3rd: Vasopressin: behavioral roles of an 'original' neuropeptide. Prog Neurobiol 2008;84:1-24.

33 Lee HJ, Macbeth AH, Pagani JH, Young WS 3rd: Oxytocin: the great facilitator of life. Prog Neurobiol 2009;88:127-151.

34 Gainer H, Yamashita M, Fields RL, House SB, Rusnak M: The magnocellular neuronal phenotype: cell-specific gene expression in the hypothalamo-neurohypophysial system. Prog Brain Res 2002;139:1-14.

>35 de Vries GJ, Miller MA: Anatomy and function of extrahypothalamic vasopressin systems in the brain. Prog Brain Res 1998;119: 3-20.

-36 De Vries GJ, Panzica GC: Sexual differentiation of central vasopressin and vasotocin systems in vertebrates: different mechanisms, similar endpoints. Neuroscience 2006;138:947-955.

37 Gainer H, Wray S: Oxytocin and vasopressin. From genes to peptides. Ann NY Acad Sci 1992;652:14-28.

38 Gwee PC, Amemiya CT, Brenner S, Venkatesh B: Sequence and organization of coelacanth neurohypophysial hormone genes: evolutionary history of the vertebrate neurohypophysial hormone gene locus. BMC Evol Biol 2008;8:93.

39 Stafflinger E, Hansen KK, Hauser F, Schneider M, Cazzamali G, Williamson M, Grimmelikhuijzen CJ: Cloning and identification of an oxytocin/vasopressin-like receptor and its ligand from insects. Proc Natl Acad Sci USA 2008;105:3262-3267.
40 Hara Y, Battey J, Gainer H: Structure of mouse vasopressin and oxytocin genes. Brain Res Mol Brain Res 1990;8:319-324.

41 Gainer H, Fields RL, House SB: Vasopressin gene expression: experimental models and strategies. Exp Neurol 2001;171:190-199.

42 Fields RL, House SB, Gainer H: Regulatory domains in the intergenic region of the oxytocin and vasopressin genes that control their hypothalamus-specific expression in vitro. J Neurosci 2003;23:7801-7809.

43 Landgraf R, Neumann ID: Vasopressin and oxytocin release within the brain: a dynamic concept of multiple and variable modes of neuropeptide communication. Front Neuroendocrinol 2004;25:150-176.

44 Leng G, Ludwig M: Neurotransmitters and peptides: whispered secrets and public announcements. J Physiol 2008;586:56255632.

45 Ludwig M, Leng G: Dendritic peptide release and peptide-dependent behaviours. Nat Rev Neurosci 2006;7:126-136.

$\checkmark 46$ Ross HE, Cole CD, Smith Y, Neumann ID, Landgraf R, Murphy AZ, Young LJ: Characterization of the oxytocin system regulating affiliative behavior in female prairie voles. Neuroscience 2009; 162:892-903.

47 Ross HE, Young LJ: Oxytocin and the neural mechanisms regulating social cognition and affiliative behavior. Front Neuroendocrinol 2009;30:534-547.

-48 Ludwig M, Sabatier N, Dayanithi G, Russell JA, Leng G: The active role of dendrites in the regulation of magnocellular neurosecretory cell behavior. Prog Brain Res 2002;139:247256.

49 Birnbaumer M: Vasopressin receptors. Trends Endocrinol Metab 2000;11:406-410.

50 Gimpl G, Reitz J, Brauer S, Trossen C: Oxytocin receptors: ligand binding, signalling and cholesterol dependence. Prog Brain Res 2008;170:193-204.

51 Manning M, Stoev S, Chini B, Durroux T, Mouillac B, Guillon G: Peptide and non-peptide agonists and antagonists for the vasopressin and oxytocin V1a, V1b, V2 and OT receptors: research tools and potential therapeutic agents. Prog Brain Res 2008;170:473512.

52 Inoue T, Kimura T, Azuma C, Inazawa J, Takemura M, Kikuchi T, Kubota Y, Ogita K, Saji F: Structural organization of the human oxytocin receptor gene. J Biol Chem 1994; 269:32451-32456.

53 Thibonnier M, Graves MK, Wagner MS, Auzan C, Clauser E, Willard HF: Structure, sequence, expression, and chromosomal localization of the human V1a vasopressin receptor gene. Genomics 1996;31:327-334.

54 Thibonnier M, Coles P, Thibonnier A, Shoham M: Molecular pharmacology and modeling of vasopressin receptors. Prog Brain Res 2002;139:179-196.

55 Gimpl G, Fahrenholz F: The oxytocin receptor system: structure, function, and regulation. Physiol Rev 2001;81:629-683. 
-56 Lolait SJ, O’Carroll AM, Mahan LC, Felder CC, Button DC, Young WS 3rd, Mezey E, Brownstein MJ: Extrapituitary expression of the rat V1b vasopressin receptor gene. Proc Natl Acad Sci USA 1995;92:6783-6787.

-57 Caldwell HK, Wersinger SR, Young WS 3rd: The role of the vasopressin $1 \mathrm{~b}$ receptor in aggression and other social behaviours. Prog Brain Res 2008;170:65-72.

58 Vaccari C, Lolait SJ, Ostrowski NL: Comparative distribution of vasopressin $\mathrm{V} 1 \mathrm{~b}$ and oxytocin receptor messenger ribonucleic acids in brain. Endocrinology 1998;139:50155033.

59 Insel TR: The challenge of translation in social neuroscience: a review of oxytocin, vasopressin, and affiliative behavior. Neuron 2010;65:768-779.

60 Lim MM, Young LJ: Neuropeptidergic regulation of affiliative behavior and social bonding in animals. Horm Behav 2006;50:506-517.

-61 Carter CS: Sex differences in oxytocin and vasopressin: implications for autism spectrum disorders? Behav Brain Res 2007;176: 170-186.

-62 Breton C, Di Scala-Guenot D, Zingg HH: Oxytocin receptor gene expression in rat mammary gland: structural characterization and regulation. J Mol Endocrinol 2001; 27:175-189.

63 Shughrue PJ, Dellovade TL, Merchenthaler I: Estrogen modulates oxytocin gene expression in regions of the rat supraoptic and paraventricular nuclei that contain estrogen receptor-beta. Prog Brain Res 2002;139:1529.

64 Ivell R, Kimura T, Muller D, Augustin K, Abend N, Bathgate R, Telgmann R, Balvers M, Tillmann G, Fuchs AR: The structure and regulation of the oxytocin receptor. Exp Physiol 2001;86:289-296.

65 Zing HH, Laporte SA: The oxytocin receptor. Trends Endocrinol Metab 2003;14:222227.

66 Hammock EA, Young LJ: Functional microsatellite polymorphism associated with divergent social structure in vole species. Mol Biol Evol 2004;21:1057-1063.

67 Mizumoto Y, Kimura T, Ivell R: A genomic element within the third intron of the human oxytocin receptor gene may be involved in transcriptional suppression. Mol Cell Endocrinol 1997;135:129-138.

68 Kusui C, Kimura T, Ogita K, Nakamura H, Matsumura Y, Koyama M, Azuma C, Murata Y: DNA methylation of the human oxytocin receptor gene promoter regulates tissuespecific gene suppression. Biochem Biophys Res Commun 2001;289:681-686.

-69 Gregory SG, Connelly JJ, Towers AJ, Johnson J, Biscocho D, Markunas CA, Lintas C, Abramson RK, Wright $\mathrm{HH}$, Ellis P, Langford CF, Worley G, Delong GR, Murphy SK, Cuccaro ML, Persico A, Pericak-Vance MA: Genomic and epigenetic evidence for oxytocin receptor deficiency in autism. BMC Med 2009;7:62.
70 Donaldson ZR, Young LJ: Oxytocin, vasopressin, and the neurogenetics of sociality. Science 2008;322:900-904.

71 Rosenblatt JS: Prepartum and postpartum regulation of maternal behaviour in the rat. Ciba Found Symp 1975;33:17-37.

72 Leng G, Meddle SL, Douglas AJ: Oxytocin and the maternal brain. Curr Opin Pharmacol 2008;8:731-734.

73 Breton C, Zingg HH: Expression and regionspecific regulation of the oxytocin receptor gene in rat brain. Endocrinology 1997;138: 1857-1862.

74 Young LJ, Muns S, Wang Z, Insel TR: Changes in oxytocin receptor $\mathrm{mRNA}$ in rat brain during pregnancy and the effects of estrogen and interleukin-6. J Neuroendocrinol 1997; 9:859-865.

75 Champagne F, Diorio J, Sharma S, Meaney $\mathrm{MJ}$ : Naturally occurring variations in maternal behavior in the rat are associated with differences in estrogen-inducible central oxytocin receptors. Proc Natl Acad Sci USA 2001;98:12736-12741.

76 Rosenblatt JS, Mayer AD, Giordano AL: Hormonal basis during pregnancy for the onset of maternal behavior in the rat. Psychoneuroendocrinology 1988;13:29-46.

77 Fahrbach SE, Morrell JI, Pfaff DW: Oxytocin induction of short-latency maternal behavior in nulliparous, estrogen-primed female rats. Horm Behav 1984;18:267-286.

78 Bosch OJ, Meddle SL, Beiderbeck DI, Douglas AJ, Neumann ID: Brain oxytocin correlates with maternal aggression: link to anxiety. J Neurosci 2005;25:6807-6815.

79 van Leengoed E, Kerker E, Swanson HH: Inhibition of post-partum maternal behaviour in the rat by injecting an oxytocin antagonist into the cerebral ventricles. J Endocrinol 1987;112:275-282.

80 Febo M, Numan M, Ferris CF: Functional magnetic resonance imaging shows oxytocin activates brain regions associated with mother-pup bonding during suckling. J Neurosci 2005;25:11637-11644.

81 Keverne EB, Kendrick KM: Oxytocin facilitation of maternal behavior in sheep. Ann NY Acad Sci 1992;652:83-101.

82 Kendrick KM, Da Costa AP, Broad KD, Ohkura S, Guevara R, Levy F, Keverne EB Neural control of maternal behaviour and olfactory recognition of offspring. Brain Res Bull 1997;44:383-395.

83 Hammock EA: Gene regulation as a modulator of social preference in voles. Adv Genet 2007;59:107-127.

84 Aragona BJ, Wang Z: The prairie vole ( $\mathrm{Mi}$ crotus ochrogaster): an animal model for behavioral neuroendocrine research on pair bonding. ILAR J 2004;45:35-45.

85 Young KA, Liu Y, Wang Z: The neurobiology of social attachment: a comparative approach to behavioral, neuroanatomical, and neurochemical studies. Comp Biochem Physiol C Toxicol Pharmacol 2008;148:401410.
86 Insel TR, Young L, Wang Z: Molecular aspects of monogamy. Ann NY Acad Sci 1997; 807:302-316.

87 Hammock EA, Young LJ: Oxytocin, vasopressin and pair bonding: implications for autism. Philos Trans R Soc Lond B Biol Sci 2006;361:2187-2198.

88 Young LJ, Wang Z: The neurobiology of pair bonding. Nat Neurosci 2004;7:10481054.

-89 Lim MM, Wang Z, Olazabal DE, Ren X, Terwilliger EF, Young LJ: Enhanced partner preference in a promiscuous species by manipulating the expression of a single gene. Nature 2004;429:754-757.

-90 Insel TR, Winslow JT, Wang Z, Young LJ: Oxytocin, vasopressin, and the neuroendocrine basis of pair bond formation. Adv Exp Med Biol 1998;449:215-224.

-91 Young LJ, Murphy Young AZ, Hammock EA: Anatomy and neurochemistry of the pair bond. J Comp Neurol 2005;493:51-57.

$\checkmark 92$ Hammock EA, Young LJ: Variation in the vasopressin V1a receptor promoter and expression: implications for inter- and intraspecific variation in social behaviour. Eur J Neurosci 2002;16:399-402.

93 Hammock EA, Young LJ: Microsatellite instability generates diversity in brain and sociobehavioral traits. Science 2005;308: 1630-1634.

94 Dantzer R, Bluthe RM, Koob GF, Le Moal M: Modulation of social memory in male rats by neurohypophyseal peptides. Psychopharmacology (Berl) 1987;91:363-368.

$\checkmark 95$ Bielsky IF, Young LJ: Oxytocin, vasopressin, and social recognition in mammals. Peptides 2004;25:1565-1574.

$\checkmark 96$ Choleris E, Clipperton-Allen AE, Phan A, Kavaliers M: Neuroendocrinology of social information processing in rats and mice. Front Neuroendocrinol 2009;30:442-459.

$\checkmark 97$ Ferguson JN, Young LJ, Insel TR: The neuroendocrine basis of social recognition. Front Neuroendocrinol 2002;23:200-224.

-98 Ferguson JN, Young LJ, Hearn EF, Matzuk MM, Insel TR, Winslow JT: Social amnesia in mice lacking the oxytocin gene. Nat Genet 2000;25:284-288.

-99 Takayanagi Y, Yoshida M, Bielsky IF, Ross HE, Kawamata M, Onaka T, Yanagisawa T, Kimura T, Matzuk MM, Young LJ, Nishimori K: Pervasive social deficits, but normal parturition, in oxytocin receptor-deficient mice. Proc Natl Acad Sci USA 2005; 102:16096-16101.

100 Winslow JT, Insel TR: The social deficits of the oxytocin knockout mouse. Neuropeptides 2002;36:221-229.

101 Ferguson JN, Aldag JM, Insel TR, Young LJ: Oxytocin in the medial amygdala is essential for social recognition in the mouse. J Neurosci 2001;21:8278-8285. 
$>_{102}$ Choleris E, Little SR, Mong JA, Puram SV, 114 Turner RA, Altemus M, Enos T, Cooper B, Langer R, Pfaff DW: Microparticle-based delivery of oxytocin receptor antisense DNA in the medial amygdala blocks social recognition in female mice. Proc Natl Acad Sci USA 2007;104:4670-4675.

103 Dluzen DE, Muraoka S, Engelmann M, Landgraf R: The effects of infusion of arginine vasopressin, oxytocin, or their antagonists into the olfactory bulb upon social recognition responses in male rats. Peptides 1998;19:999-1005.

104 Goodson JL, Kabelik D: Dynamic limbic networks and social diversity in vertebrates: from neural context to neuromodulatory patterning. Front Neuroendocrinol 2009;30:429-441.

-105 Skuse DH, Gallagher L: Dopaminergicneuropeptide interactions in the social brain. Trends Cogn Sci 2009;13:27-35.

-106 Engelmann M, Landgraf R: Microdialysis administration of vasopressin into the septum improves social recognition in Brattleboro rats. Physiol Behav 1994;55:145-149.

-107 Bielsky IF, Hu SB, Szegda KL, Westphal H, Young LJ: Profound impairment in social recognition and reduction in anxiety-like behavior in vasopressin $\mathrm{Vla}$ receptor knockout mice. Neuropsychopharmacology 2004;29:483-493.

-108 Bielsky IF, Hu SB, Ren X, Terwilliger EF, Young LJ: The V1a vasopressin receptor is necessary and sufficient for normal social recognition: a gene replacement study. Neuron 2005;47:503-513.

109 Tobin VA, Hashimoto H, Wacker DW, Takayanagi Y, Langnaese K, Caquineau C, Noack J, Landgraf R, Onaka T, Leng G, Meddle SL, Engelmann M, Ludwig M: An intrinsic vasopressin system in the olfactory bulb is involved in social recognition. Nature 2010;464:413-417.

-110 Born J, Lange T, Kern W, McGregor GP, Bickel U, Fehm HL: Sniffing neuropeptides: a transnasal approach to the human brain. Nat Neurosci 2002;5:514-516.

-111 Amico JA, Johnston JM, Vagnucci AH: Suckling-induced attenuation of plasma cortisol concentrations in postpartum lactating women. Endocr Res 1994;20:79-87.

-112 Chiodera P, Salvarani C, Bacchi-Modena A, Spallanzani R, Cigarini C, Alboni A, Gardini E, Coiro V: Relationship between plasma profiles of oxytocin and adrenocorticotropic hormone during suckling or breast stimulation in women. Horm Res 1991;35: 119-123.

-113 Heinrichs M, Meinlschmidt G, Neumann I, Wagner S, Kirschbaum C, Ehlert U, Hellhammer DH: Effects of suckling on hypothalamic-pituitary-adrenal axis responses to psychosocial stress in postpartum lactating women. J Clin Endocrinol Metab 2001; 86:4798-4804. McGuinness T: Preliminary research on plasma oxytocin in normal cycling women: investigating emotion and interpersonal distress. Psychiatry 1999;62:97-113.

115 Heinrichs M, Baumgartner T, Kirschbaum C, Ehlert U: Social support and oxytocin interact to suppress cortisol and subjective responses to psychosocial stress. Biol Psychiatry 2003;54:1389-1398.

116 Ditzen B, Schaer M, Gabriel B, Bodenmann G, Ehlert U, Heinrichs M: Intranasal oxytocin increases positive communication and reduces cortisol levels during couple conflict. Biol Psychiatry 2009;65:728-731.

117 Domes G, Lischke A, Berger C, Grossmann A, Hauenstein K, Heinrichs M, Herpertz SC: Effects of intranasal oxytocin on emotional face processing in women. Psychoneuroendocrinology 2010;35:83-93.

118 Petrovic P, Kalisch R, Singer T, Dolan RJ: Oxytocin attenuates affective evaluations of conditioned faces and amygdala activity. J Neurosci 2008;28:6607-6615.

119 Kirsch P, Esslinger C, Chen Q, Mier D, Lis S, Siddhanti S, Gruppe H, Mattay VS, Gallhofer B, Meyer-Lindenberg A: Oxytocin modulates neural circuitry for social cognition and fear in humans. J Neurosci 2005; 25:11489-11493.

120 Meyer-Lindenberg A: Impact of prosocial neuropeptides on human brain function. Prog Brain Res 2008;170:463-470.

121 Kosfeld M, Heinrichs M, Zak PJ, Fischbacher U, Fehr E: Oxytocin increases trust in humans. Nature 2005;435:673-676.

122 Baumgartner T, Heinrichs M, Vonlanthen A, Fischbacher U, Fehr E: Oxytocin shapes the neural circuitry of trust and trust adaptation in humans. Neuron 2008;58:639650.

123 Domes G, Heinrichs M, Michel A, Berger C, Herpertz SC: Oxytocin improves 'mindreading' in humans. Biol Psychiatry 2007; 61:731-733

124 Guastella AJ, Mitchell PB, Dadds MR: Oxytocin increases gaze to the eye region of human faces. Biol Psychiatry 2008;63:3-5.

125 Theodoridou A, Rowe AC, Penton-Voak IS, Rogers PJ: Oxytocin and social perception: oxytocin increases perceived facial trustworthiness and attractiveness. Horm Behav 2009;56:128-132.

126 Di Simplicio M, Massey-Chase R, Cowen PJ, Harmer CJ: Oxytocin enhances processing of positive versus negative emotional information in healthy male volunteers. J Psychopharmacol 2009;23:241-248.

127 Guastella AJ, Mitchell PB, Mathews F: Oxytocin enhances the encoding of positive social memories in humans. Biol Psychiatry 2008;64:256-258.
128 Feldman R, Gordon I, Schneiderman I, Weisman O, Zagoory-Sharon O: Natural variations in maternal and paternal care are associated with systematic changes in oxytocin following parent-infant contact. Psychoneuroendocrinology 2010;35:1133-1141.

129 Gordon I, Zagoory-Sharon O, Leckman JF, Feldman R: Oxytocin and the development of parenting in humans. Biol Psychiatry 2010;68:377-382.

130 Naber F, van Ijzendoorn MH, Deschamps $\mathrm{P}$, van Engeland $\mathrm{H}$, Bakermans-Kranenburg MJ: Intranasal oxytocin increases fathers' observed responsiveness during play with their children: a double-blind withinsubject experiment. Psychoneuroendocrinology 2010, E-pub ahead of print.

131 Shamay-Tsoory SG, Fischer M, Dvash J, Harari H, Perach-Bloom N, Levkovitz Y: Intranasal administration of oxytocin increases envy and schadenfreude (gloating). Biol Psychiatry 2009;66:864-870.

132 Guastella AJ, Carson DS, Dadds MR, Mitchell PB, Cox RE: Does oxytocin influence the early detection of angry and happy faces? Psychoneuroendocrinology 2009;34: 220-225.

133 Tops M: Oxytocin: envy or engagement in others? Biol Psychiatry 2010;67:e5-e6, author reply e7.

134 De Dreu CK, Greer LL, Handgraaf MJ, Shalvi S, Van Kleef GA, Baas M, Ten Velden FS, Van Dijk E, Feith SW: The neuropeptide oxytocin regulates parochial altruism in intergroup conflict among humans. Science 2010;328:1408-1411.

135 Ebstein RP, Israel S, Chew SH, Zhong S, Knafo A: Genetics of human social behavior. Neuron 2010;65:831-844.

136 Israel S, Lerer E, Shalev I, Uzefovsky F, Reibold M, Bachner-Melman R, Granot R, Bornstein G, Knafo A, Yirmiya N, Ebstein RP: Molecular genetic studies of the arginine vasopressin 1a receptor (AVPR1a) and the oxytocin receptor (OXTR) in human behaviour: from autism to altruism with some notes in between. Prog Brain Res 2008;170:435-449.

137 Knafo A, Israel S, Darvasi A, Bachner-Melman R, Uzefovsky F, Cohen L, Feldman E, Lerer E, Laiba E, Raz Y, Nemanov L, Gritsenko I, Dina C, Agam G, Dean B, Bornstein G, Ebstein RP: Individual differences in allocation of funds in the dictator game associated with length of the arginine vasopressin 1a receptor RS3 promoter region and correlation between RS3 length and hippocampal mRNA. Genes Brain Behav 2008;7:266-275.

138 Walum H, Westberg L, Henningsson S, Neiderhiser JM, Reiss D, Igl W, Ganiban JM, Spotts EL, Pedersen NL, Eriksson E, Lichtenstein P: Genetic variation in the vasopressin receptor 1a gene (AVPR1A) associates with pair-bonding behavior in humans. Proc Natl Acad Sci USA 2008;105: 14153-14156. 
139 Prichard ZM, Mackinnon AJ, Jorm AF, $>152$ de Vries GJ: Sex differences in vasopressin Easteal S: AVPR1A and OXTR polymorphisms are associated with sexual and reproductive behavioral phenotypes in humans. Mutation in brief No. 981. Online. Hum Mutat 2007;28:1150.

140 Meyer-Lindenberg A, Kolachana B, Gold B, Olsh A, Nicodemus KK, Mattay V, Dean M, Weinberger DR: Genetic variants in AVPR1A linked to autism predict amygdala activation and personality traits in healthy humans. Mol Psychiatry 2009;14: 968-975.

-141 Rodrigues SM, Saslow LR, Garcia N, John OP, Keltner D: Oxytocin receptor genetic variation relates to empathy and stress reactivity in humans. Proc Natl Acad Sci USA 2009;106:21437-21441.

142 Bakermans-Kranenburg MJ, van Ijzendoorn MH: Oxytocin receptor (OXTR) and serotonin transporter (5-HTT) genes associated with observed parenting. Soc Cogn Affect Neurosci 2008;3:128-134.

143 Riem MM, Pieper S, Out D, BakermansKranenburg MJ, van Ijzendoorn $\mathrm{MH}$ : Oxytocin receptor gene and depressive symptoms associated with physiological reactivity to infant crying. Soc Cogn Affect Neurosci 2010, E-pub ahead of print.

-144 Israel S, Lerer E, Shalev I, Uzefovsky F, Riebold M, Laiba E, Bachner-Melman R, Maril A, Bornstein G, Knafo A, Ebstein RP: The oxytocin receptor (OXTR) contributes to prosocial fund allocations in the dictator game and the social value orientations task. PLoS One 2009; 4:e5535.

-145 Ebstein RP, Israel S, Lerer E, Uzefovsky F, Shalev I, Gritsenko I, Riebold M, Salomon $\mathrm{S}$, Yirmiya N: Arginine vasopressin and oxytocin modulate human social behavior. Ann NY Acad Sci 2009;1167:87-102.

-146 Insel TR, O’Brien DJ, Leckman JF: Oxytocin, vasopressin, and autism: is there a connection? Biol Psychiatry 1999;45:145-157.

-147 Baron-Cohen S, Ring HA, Bullmore ET, Wheelwright S, Ashwin C, Williams SC: The amygdala theory of autism. Neurosci Biobehav Rev 2000;24:355-364.

148 Schulkin J: Autism and the amygdala: an endocrine hypothesis. Brain Cogn 2007;65: 87-99.

-149 Domes G, Heinrichs M, Glascher J, Buchel C, Braus DF, Herpertz SC: Oxytocin attenuates amygdala responses to emotional faces regardless of valence. Biol Psychiatry 2007;62:1187-1190.

$>150$ Winslow JT, Insel TR: Neuroendocrine basis of social recognition. Curr Opin Neurobiol 2004; 14:248-253.

-151 Yamasue H, Kuwabara H, Kawakubo Y, Kasai K: Oxytocin, sexually dimorphic features of the social brain, and autism. Psychiatry Clin Neurosci 2009;63:129-140. and oxytocin innervation of the brain. Prog Brain Res 2008;170:17-27.

153 Modahl C, Green L, Fein D, Morris M, Waterhouse L, Feinstein C, Levin H: Plasma oxytocin levels in autistic children. Biol Psychiatry 1998;43:270-277.

154 Green L, Fein D, Modahl C, Feinstein C, Waterhouse L, Morris M: Oxytocin and autistic disorder: alterations in peptide forms. Biol Psychiatry 2001;50:609-613.

-155 Andari E, Duhamel JR, Zalla T, Herbrecht E, Leboyer M, Sirigu A: Promoting social behavior with oxytocin in high-functioning autism spectrum disorders. Proc Natl Acad Sci USA 2010;107:4389-4394.

156 Jansen LM, Gispen-de Wied CC, Wiegant VM, Westenberg HG, Lahuis BE, van Engeland $\mathrm{H}$ : Autonomic and neuroendocrine responses to a psychosocial stressor in adults with autistic spectrum disorder. J Autism Dev Disord 2006;36:891-899.

157 Lauritsen MB, Als TD, Dahl HA, Flint TJ, Wang AG, Vang M, Kruse TA, Ewald $H$, Mors O: A genome-wide search for alleles and haplotypes associated with autism and related pervasive developmental disorders on the Faroe Islands. Mol Psychiatry 2006; 11:37-46.

158 McCauley JL, Li C, Jiang L, Olson LM, Crockett G, Gainer K, Folstein SE, Haines JL, Sutcliffe JS: Genome-wide and OrderedSubset linkage analyses provide support for autism loci on $17 \mathrm{q}$ and $19 \mathrm{p}$ with evidence of phenotypic and interlocus genetic correlates. BMC Med Genet 2005;6:1

159 Sebat J, Lakshmi B, Malhotra D, Troge J, Lese-Martin C, Walsh T, Yamrom B, Yoon S, Krasnitz A, Kendall J, Leotta A, Pai D, Zhang R, Lee YH, Hicks J, Spence SJ, Lee AT, Puura K, Lehtimaki T, Ledbetter D, Gregersen PK, Bregman J, Sutcliffe JS, Jobanputra V, Chung W, Warburton D, King MC, Skuse D, Geschwind DH, Gilliam TC, Ye K, Wigler M: Strong association of de novo copy number mutations with autism. Science 2007;316:445-449.

160 Jacob S, Brune CW, Carter CS, Leventhal BL, Lord C, Cook EH Jr: Association of the oxytocin receptor gene (OXTR) in Caucasian children and adolescents with autism. Neurosci Lett 2007;417:6-9.

161 Liu X, Kawamura Y, Shimada T, Otowa T, Koishi S, Sugiyama T, Nishida H, Hashimoto O, Nakagami R, Tochigi M, Umekage T, Kano Y, Miyagawa T, Kato N, Tokunaga K, Sasaki T: Association of the oxytocin receptor (OXTR) gene polymorphisms with autism spectrum disorder (ASD) in the Japanese population. J Hum Genet 2010;55: 137-141.

162 Lerer E, Levi S, Salomon S, Darvasi A, Yirmiya N, Ebstein RP: Association between the oxytocin receptor (OXTR) gene and autism: relationship to Vineland Adaptive Behavior Scales and cognition. Mol Psychiatry 2008;13:980-988.
163 Wu S, Jia M, Ruan Y, Liu J, Guo Y, Shuang M, Gong X, Zhang Y, Yang X, Zhang D: Positive association of the oxytocin receptor gene (OXTR) with autism in the Chinese Han population. Biol Psychiatry 2005;58: 74-77.

164 Yrigollen CM, Han SS, Kochetkova A, Babitz T, Chang JT, Volkmar FR, Leckman JF, Grigorenko EL: Genes controlling affiliative behavior as candidate genes for autism. Biol Psychiatry 2008;63:911-916.

165 Tansey KE, Brookes KJ, Hill MJ, Cochrane LE, Gill M, Skuse D, Correia C, Vicente A, Kent L, Gallagher L, Anney RJ: Oxytocin receptor (OXTR) does not play a major role in the aetiology of autism: genetic and molecular studies. Neurosci Lett 2010;474: 163-167.

166 Kim SJ, Young LJ, Gonen D, VeenstraVanderWeele J, Courchesne R, Courchesne E, Lord C, Leventhal BL, Cook EH Jr, Insel TR: Transmission disequilibrium testing of argininevasopressin receptor 1A(AVPR1A) polymorphisms in autism. Mol Psychiatry 2002;7:503-507.

167 Wassink TH, Piven J, Vieland VJ, Pietila J, Goedken RJ, Folstein SE, Sheffield VC: Examination of AVPR1a as an autism susceptibility gene. Mol Psychiatry 2004;9:968972.

168 Yirmiya N, Rosenberg C, Levi S, Salomon S, Shulman C, Nemanov L, Dina C, Ebstein RP: Association between the arginine vasopressin 1a receptor (AVPR1a) gene and autism in a family-based study: mediation by socialization skills. Mol Psychiatry 2006; 11:488-494.

169 Hollander E, Novotny S, Hanratty M, Yaffe R, DeCaria CM, Aronowitz BR, Mosovich $\mathrm{S}$ : Oxytocin infusion reduces repetitive behaviors in adults with autistic and Asperger's disorders. Neuropsychopharmacology 2003;28:193-198.

170 Hollander E, Bartz J, Chaplin W, Phillips A, Sumner J, Soorya L, Anagnostou E, Wasserman S: Oxytocin increases retention of social cognition in autism. Biol Psychiatry 2007;61:498-503.

171 Bartz JA, Hollander E: Oxytocin and experimental therapeutics in autism spectrum disorders. Prog Brain Res 2008;170:451462.

172 Guastella AJ, Einfeld SL, Gray KM, Rinehart NJ, Tonge BJ, Lambert TJ, Hickie IB: Intranasal oxytocin improves emotion recognition for youth with autism spectrum disorders. Biol Psychiatry 2010;67:692-694.

173 Heinrichs M, von Dawans B, Domes G: Oxytocin, vasopressin, and human social behavior. Front Neuroendocrinol 2009;30: 548-557. 